\title{
THE ANALYSIS OF LANDS IN SECURITY ZONES OF HIGH-VOLTAGE POWER LINES (POWER LINE) ON THE EXAMPLE OF THE FERGANA REGION
}

\author{
Abdullayev Ibrohim Numanovich ${ }^{1}$ \\ $\mathrm{PhD}$ of Fergana polytechnic institute, \\ Uzbekistan
}

\author{
Marupov Azizxon Abbosxonovich ${ }^{2}$ \\ $\mathrm{PhD}$ applicant of Fergana polytechnic \\ institute, \\ Uzbekistan
}

Article DOI: https://doi.org/10.36713/epra3977

\begin{abstract}
ANNOTATION
Practice shows that the lack or late receipt of information with special conditions for the use of territories often has a negative impact not only on the budget and time frame for the construction of a real estate facility, but also on the fate of the built facility in general. The protection areas of underground and above-ground engineering communications play an important role for the future in land use. And also, when using these lands for agricultural needs, with the correct organization of cadastral relations represents the relevance of the issue under study. In the present, as an example, a section of high-voltage power transmission lines (power lines) of $1 \mathrm{~km}$ length is presented.

KEY WORDS: security zones, land plot, information about zones, high-voltage zones, power transmission lines, pipelines, gas pipelines, bonality score, engineering networks, construction of buildings and structures.
\end{abstract}

\section{INTRODUCTION}

The security zone is installed depending on the type of protected object. The list of types of zones of the Fergana region is established by the Land Code of the Republic of Uzbekistan, according to which 28 types of zones with special conditions of use of the territory are defined, for example, security zones of pipelines, electric grid facilities, lines of structures and communication, roadside lanes, etc.

\section{OBJECTIVES}

Depending on the type of zones within its territory, certain restrictions on the use of land plots are established. These restrictions are mainly related to the possibility of placing capital construction facilities in principle, or compliance with certain parameters of the object under construction, carrying out certain construction works. [1]

First, when using a land plot, it is important to know what security zones are available on the plot. When checking the planned land plot for acquisition, special attention should be paid to engineering networks located within its borders or in adjacent plots. For example, around a surface or underground pipeline there is a security zone, the regime of which can be an unpleasant surprise for the developer, especially for underground structures, which cannot be visually detected. [1]

Any protection zone implies restrictions on the targeted use of the land plot. The security zone of the gas pipeline or the power line can entail the ban on construction of any buildings, buildings and constructions. The presence of a sanitary protection zone indicates a ban on the construction of residential facilities. The presence of a cable means that any earthworks are carried out only if the organization - owner of such a cable line - agrees.

Land plots are not seized from their owners, land users, landowners and tenants, but within the boundaries of these plots a special regime may be introduced for their use, limiting or prohibiting those activities that are incompatible with the purpose of establishing such zones.

If the land user has doubts about the correctness of the established size of the security zone, it is possible to contact the cadastral engineer to check the distance from the object in connection with the location of which the zone is installed to the boundaries of the land plot and compare it with that entered in the Unified State Register of Real Estate (EGRN). If they do not coincide, and it is obvious that the site does not enter the security zone, then it is necessary to write a letter to the operating organization demanding to reconsider the boundaries of the security zone.

\section{METHODOLOGY}

In this article studied and the example shows high voltage areas of power transmission lines.

Land use in such zones without harmonization is subject to such responsibilities for officials of organizations as disciplinary liability, and 
further, depending on the consequences, administrative or criminal liability may arise. For example, work in the security zone of the power grid line without the approval of the organization can cause accidents and harm the health of the persons carrying out the work. It is obvious that the official will be prosecuted for such an incident. If it is the actions of an organization whose work has led to the failure of the energy system, it will first of all be civil consequences and compensation for losses.

If the security zone does not allow using the land plot for the intended purpose, losses are recovered from the owner of the object for which the security zone is installed. If damages are not compensated or are not compensated in a small amount, the court should be contacted.

\section{STATISTICAL DESIGN}

The area of Uzbekistan is about 450 thousand $\mathrm{km} 2$, of which $60 \%$ of the territory are deserts, $20 \%$ mountain masses and only $20 \%$ is used by the population.
Fergana region occupies more than 7 thousand $\mathrm{km} 2$, which is $1.56 \%$ of the total area of Uzbekistan. [2]

Providing the population and all industrial potential, such sources of life as heat, gas, energy and water supply force to alienate large areas for the laying of communication networks.

Such demographic conditions, environmental issues, careful and unsustainable treatment of land require careful study and analysis of all underground, aboveground and air communication networks.

The transit corridor of only high-voltage power lines with a width of $150 \mathrm{~m}$ laid through the Fergana region has a length of more than $100 \mathrm{~km}$ occupies 1500 hectares of land belonging to an average of 56 points of agricultural land. [3]

For example, only in the city of Fergana there are underground and air power lines for more than $975 \mathrm{~km}$ (Table-1). However, the listed width of the security strip on the territory of the city is in non-economic use, either under the roads or under well-equipped squares.

Power line of the city of Fergana. Table-1.

\begin{tabular}{|l|l|c|c|}
\hline \multicolumn{1}{|c|}{ No } & \multicolumn{1}{|c|}{ View of the power line } & Length, km. & $\begin{array}{c}\text { Standard width of } \\
\text { guard zone, m. }\end{array}$ \\
\hline 1. & Low-voltage cable line $(0,4 \mathrm{kw})$. & 81,253 & 2 \\
\hline 2. & Low-voltage air-line $(0,4 \mathrm{kw})$. & 574,988 & 2 \\
\hline 3. & High-voltage cable line $(10 / 6 \mathrm{kw})$. & 202,197 & 20 \\
\hline 4. & High-voltage air-line $(10 / 6 \mathrm{kw})$. & 116,25 & 20 \\
\hline \multicolumn{2}{|c|}{ Total: } & $\mathbf{9 7 4 , 6 8 8}$ & 44 \\
\hline
\end{tabular}

All issues and legal actions for the use and proper use of lands concerning the protection zones of the EB LINE of the Republic of Uzbekistan are regulated by Cabinet of Ministers Decision No. 93 of 17 May 2010. The resolution briefly and clearly describes the rules of the security facilities of the electric grid farm. In the annex of this resolution the following rules are taken into account when placing the facilities of the electric grid farm:

- Land plots for the construction of electric grid facilities are allocated in accordance with the procedure established by the legislation of the Republic of Uzbekistan;

- The protection zone of electric grid facilities is the surface of the plot of land or the bottom of the water space, on which a special order of ownership and use of the land plot or water space is established. The protection areas of the electric grid facilities established in accordance with these Rules are encumbrances of land plots and are subject to state registration in accordance with the established procedure;

- Ownerships and legal entities responsible for the objects of the power grid are obliged to transfer the materials of the executive top geodetic survey of the routes to the territorial bodies of architecture and construction for their application in the corresponding maps of land use;

- Protection zones of electric grid facilities are established in kind by district services on land resources in rural areas, real estate cadastral services in cities and towns in cadastral division of territory and cadastral surveys of land plots and are subject to mandatory registration in the cadastral business and display on the cadastral plan of the land plot;

- Design and estimate documentation for construction, reconstruction of objects that can be a source of contamination and corrosion of electric grid facilities shall provide measures limiting pollution and corrosion or removal of electric grid facilities from the contamination zone (corrosion);

- The land area of the protection zones of existing electricity grid facilities is not subject to seizure from owners of land plots, landowners and land users, including tenants;

- In special cases, with the permission of the Cabinet of Ministers of the Republic of Uzbekistan, it is allowed to build electric grid facilities in protected natural areas, state reserves, protected areas of natural parks, state biosphere reserves, etc.

The following protection zones of the power grid facilities are established by these Regulations:

A) along overhead power transmission lines in the form of a land plot and airspace limited by vertical planes standing on both sides of the line from extreme wires at a distance, Table-2: 
for voltage lines (Table-2):

\begin{tabular}{|c|c|c|}
\hline № & Voltage lines, kw. & Width security zones, m. \\
\hline 1. & 20 & 10 \\
\hline 2. & 35 & 15 \\
\hline 3. & 110 & 20 \\
\hline 4. & 220 & 25 \\
\hline 5. & 500 & 30 \\
\hline
\end{tabular}

B) along overhead power transmission lines up to 1000 volts (except for branches to entrances to buildings) in the form of a plot of land limited by parallel straight lines, standing from projections of extreme wires to the ground surface (in case their position is not closed) by 2 meters on each side;

C) along underground cable power transmission lines in the form of a plot of land limited by parallel straight lines standing from extreme cables by 1 meter on each side, and when cable lines pass in cities under sidewalks - by 0.6 meters towards buildings and structures and by 1 meter towards the street roadway;

D) along underwater power transmission cable lines in the form of a section of water space from the water surface to the bottom enclosed between vertical planes standing from extreme cables to 100 meters on each side.
The minimum permissible distances between power transmission lines and the nearest buildings and structures, as well as wood and other perennial plantations, are determined on the basis of the rules of design and arrangement of electrical installations.

\section{GEOGRAPHICAL AREA}

Figure-1 shows an example of laying 5, 10/6 kilowatt overhead power transmission lines ("transverse" view) around the town of Fergana, in the Kirgili area, crossing the streets of Fergana and Sh.Rashidova along to the west.

Picture-1 Parallel air power lines in the city of Fergana, Sh.Rashidova Street (transverse view)

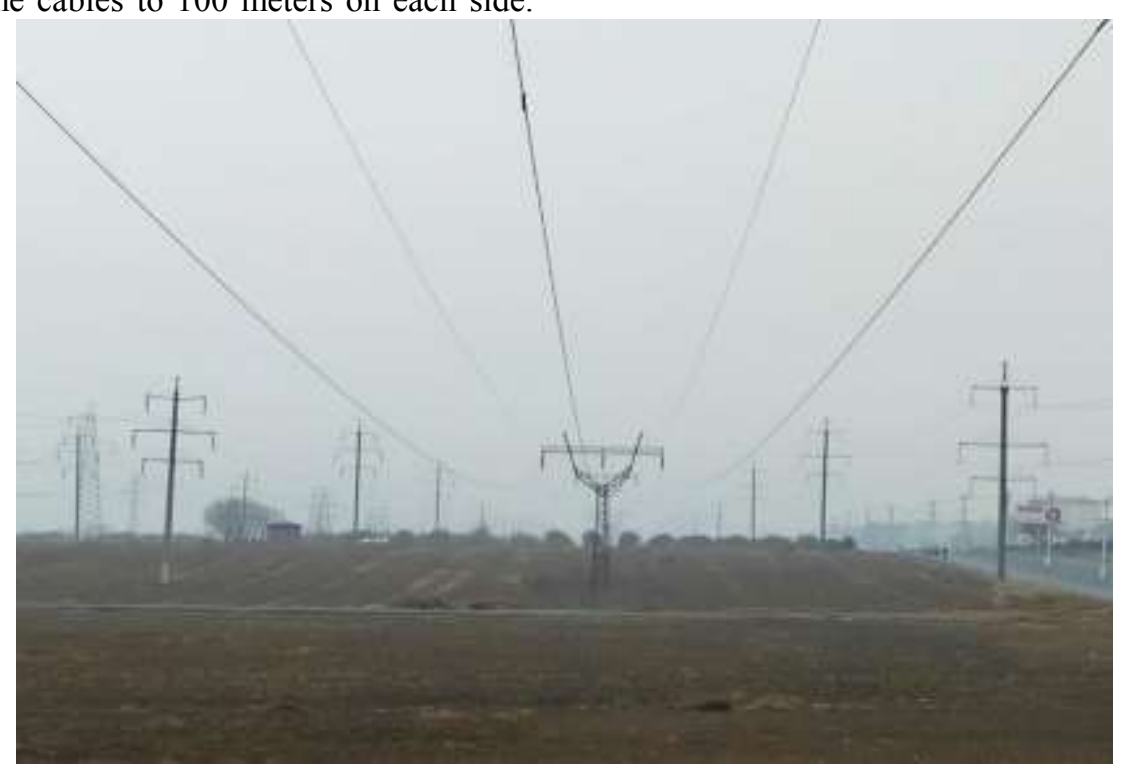

Picture-2. Displays this strip of about 10 hectares in plan view. It clearly shows the location of all the power lines 5. From the east runs Ferganskaya Street, to the north Sh.Rashidova Street. As can be seen from the 1 from the roof of the power line to the multi-storey residential buildings, the roadway and a strip of green plantations are open. However, south between the 5 of the LEP and the individual private development, the security zone has been disrupted. On the north-west part between 1 and 3 of it the line ( 3 ha) is occupied by dwarfs of fruit plantations. The rest of the strip ( $7 \mathrm{ha}$ ) despite the suitability is inactive.

In order to ensure the absence of pressure, it should also be noted that when the power lines are cut across the street of Ferganskaya, frame lighting supports for the protection of the roadway from the break of wires are removed, as well as road signs prohibiting the stoning and parking under the power lines.

\section{RESULTS}

In this case, the analysis of the 500-600 m long strip shows the istic age of the security zone. Taking into account such facts as the laying of 5 power lines at various times, from the 1950s to the 1990s, the formation and various reasons for development in border security zones, etc., it is concluded that a hundred in the past the rules of placement of electric grid facilities and alienation of land plots have not always been observed. Thorough and meticulous study and analysis of the power line corridor under consideration over the whole length to reveal many positive and negative aspects of the functioning of only one security zone of power supply. 


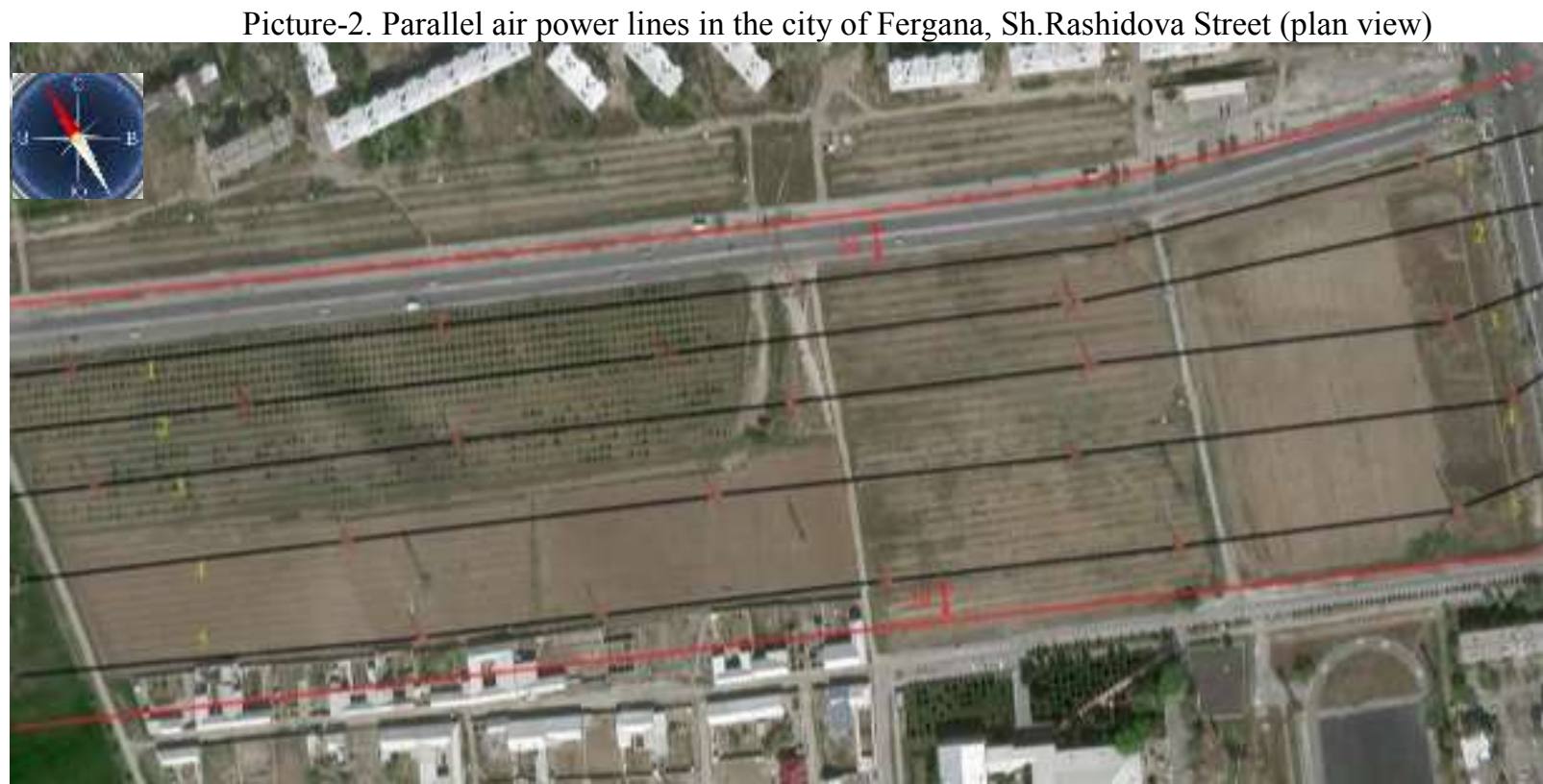

The size of the protected areas of electric grid facilities in protected natural areas in the cases provided for in paragraph 11 of these Rules and their regime shall be established by the enterprise in charge of the electric grid facilities, in agreement with the State Ecology Committee of the Republic of Uzbekistan. Construction of roads, entrances and other structures for operational maintenance of electric grid facilities is carried out on the basis of projects that have received a positive conclusion of the State Ecological Expertise [4].

\section{SUGGESTIONS}

Owners of electric grid facilities in protected areas and on leaks are allowed:

- Construction of roads, entrances and other structures necessary for maintenance of power grid facilities (by additional agreement for land removal and abutment to public roads);

- Opening of pits, trenches and pits for repair of these electric grid facilities with mandatory backfilling and land recultivation;

- Trimming trees both to ensure a set width of seeps and height limits.

If there are electric grid facilities on sites allocated for industrial and other construction, as well as for agricultural purposes, organizations that have received these sites are obliged to coordinate their use with the corresponding owners of electric grid facilities. [4]

\section{CONCLUSION}

Considering that there are many such zones in the region, in the valley and in the Republic, the practical study of analysis and theoretical comprehensive study provides an opportunity to develop recommendations on the regularization of the state of the protected zones, the design and alienation of new protected zones. This is important in the rapid development of the energy complex of the country. When laying new communication networks in the construction of wind power plants and solar panels, which require large areas for construction. Our careful and insensitive attitude towards land should increase the efficiency of land use with environmental cleanliness and transfer it to new generations.

\section{REFERENCES}

1. http://library.ziyonet.uz/ru/book/download/34 264

2. https://ru.wikipedia.org/wiki/\%D0\%A3\%D0\% B7\%D0\%B1\%D0\%B5\%D0\%BA\%D0\%B8\% D1\%81\%D1\%82\%D0\%B0\%D0\%BD

3. Kamolot Xakimova, Azizxon Marupov, Gulshanoy Mirzakarimova. (2019), "Maintaining Cadastral Valuation for the Effective Use of Agricultural Lands of the Fergana Region", INTERNATIONAL JOURNAL OF ADVANCED RESEARCH IN SCIENCE, ENGINEERING AND TECHNOLOGY, India, p.p: 11022-11026

4. Cabinet of Ministers Republic of Uzbekistan, Decision No. 915 of 14 November 2017 National Database of Legislation, 15.11.2017 2., № 09/17/915/0259 